\title{
A T Cell-dependent Experimental Liver Injury in Mice Inducible by Concanavalin A
}

\author{
G. Tiegs, ${ }^{\star}$ J. Hentschel, ${ }^{\star}$ and A. Wendel* \\ *Departments of Biochemical Pharmacology and ${ }^{\ddagger}$ Ultrastructure Research, Faculty of Biology, \\ University of Konstanz, D-7750 Konstanz, Federal Republic of Germany
}

\begin{abstract}
Male NMRI or BALB/c mice developed severe liver injury as assessed by transaminase release within $8 \mathrm{~h}$ when an intravenous dose $>1.5 \mathrm{mg} / \mathrm{kg}$ concanavalin $\mathrm{A}$ (Con A) was given. Histopathologically, only the liver was affected. Electron micrographs revealed leukocyte sticking to endothelial cells and bleb formation of hepatocytes. The hepatotoxicity of the lectin correlated neither with its agglutination activity nor with its sugar specificity. Administration of $0.5 \mathrm{mg} / \mathrm{kg}$ dexamethasone or $50 \mathrm{mg} / \mathrm{kg}$ cyclosporine A or $50 \mathrm{mg} / \mathrm{kg}$ FK 506 (Fujimycin) resulted in protection of the animals whereas indomethacin pretreatment failed to protect. Con $A$ hepatitis was accompanied by the release of IL-2 into the serum of the animals. Mice with severe combined immunodeficiency syndrome lacking $B$ as well as T lymphocytes were resistant against Con A. Athymic nude mice with immature $T$ lymphocytes were also resistant. Pretreatment of mice with an antibody against $T$ lymphocytes fully protected against Con $A$ as did monoclonal anti-mouse CD4. Monoclonal anti-mouse CD8 failed to protect. Pretreatment of mice with silica particles, i.e., deletion of macrophages, prevented the induction of hepatitis. These findings provide evidence that Con $\mathrm{A}$-induced liver injury depends on the activation of $\mathbf{T}$ lymphocytes by macrophages in the presence of Con A. The model might allow the study of the pathophysiology of immunologically mediated hepatic disorders such as autoimmune chronic active hepatitis. (J. Clin. Invest. 1992. 90:196203.) Key words: autoimmunity • immunosuppression • lectin • lymphocytes • hepatitis
\end{abstract}

\section{Introduction}

Toxic liver disease represents a worldwide health problem in humans, which can be managed pharmacologically in only a few cases. Development of new drugs depends primarily on the availability of suitable animal models. Until now, the commonly used induction of toxic liver injury by xenobiotics hardly represents the clinical situation in human beings.

The pathophysiology of liver disease includes complex phenomena such as interorgan interrelationships on humoral basis, the highly sophisticated morphological organization of the organ itself, and the integrity of metabolic pathways and

Address reprint requests to Dr. Wendel, Faculty of Biology, University of Konstanz, P.O. Box 5560, D-7750 Konstanz, Federal Republic of Germany.

Received for publication 24 July 1990 and in revised form 11 February 1992.

J. Clin. Invest.

(c) The American Society for Clinical Investigation, Inc.

0021-9738/92/07/0196/08 \$2.00

Volume 90, July 1992, 196-203 their regulation in the individual cell types of the liver. Because of these circumstances, the development of hepatic injury cannot be easily studied in cellular systems. The currently established liver disease models in experimental animals are either based on the adverse effects of model hepatotoxins or take advantage of inherited metabolic disorders affecting the liver. Either model is prone to the limitations inherent to the experimental approach. Recently, this model spectrum has been extended by an acute inflammatory liver disease induced by LPSs from gram-negative bacteria in galactosamine-sensitized rodents, which is likely to be based on production and biological action of endogenous mediators. Among these mediators, leukotriene $\mathrm{D}_{4}$ and tumor necrosis factor- $\alpha$ (TNF) ${ }^{1}$ have been identified in a causal sequence leading to hepatitis $(1,2)$. Previous work by others suggests that macrophages represent a cell type that is primarily responsible for this pathophysiology as a recipient and sender of humoral signals (3).

Despite detailed knowledge about the reaction of lymphocytes to the inflammatory response, little is known about the contribution of this cell type to liver disorders. The widespread use of concanavalin $\mathrm{A}(\mathrm{Con} \mathrm{A})$ as a potent agent that stimulates in vitro the release of a broad spectrum of lymphokines from lymphocytes and other mononuclear cells (4) prompted us to examine whether direct administration of this lectin to animals would bring about pathophysiological events.

\section{Methods}

Animals. Male NMRI albino mice were purchased from Dr. K. Thomae $\mathrm{GmbH}$, Biberach, FRG; female BALB/c albino mice were from the Tierforschungsanlage, University of Konstanz, FRG; female $\mathrm{BALB} / \mathrm{c}$ nude mice or male $\mathrm{C} 3 \mathrm{H} / \mathrm{HeJ}$ mice were from the Hannoversches Zentralinstitut, Hannover, FRG. Mice with severe combined immunodeficiency syndrome (SCID mice) were obtained from Dr. Mossmann, MPI für Immunbiologie, Freiburg, FRG, by courtesy of the Fox Chase Cancer Center, Philadelphia, PA. All animals were kept at least $1 \mathrm{wk}$ at $22^{\circ} \mathrm{C}$ and $55 \%$ relative humidity in a 12-h day/night rhythm with free access to food and water. SCID mice were kept in an isolator box.

Dosages and application routes. Lectins were purchased from Sigma Chemical Co., St. Louis, MO, and administered to mice via a tail vein as a solution in pyrogen-free PBS in a volume of $300 \mu l . \alpha$-D-Mannose or methyl $\alpha$-D-mannopyranoside (E. Merck, Darmstadt, FRG) were incubated with $1 \mathrm{mg} / \mathrm{ml} \mathrm{Con} A$ in a concentration of $54 \mathrm{mg} / \mathrm{ml}$ hexose for $30 \mathrm{~min} .600 \mu \mathrm{l}$ of either solution was injected intravenously. This corresponds to a dose of $20 \mathrm{mg} / \mathrm{kg}$ Con A and $1,080 \mathrm{mg} / \mathrm{kg}$ hexose.

$500 \mu \mathrm{g} / \mathrm{kg}$ dexamethasone (Sigma Chemical Co.) was administered intraperitoneally $1 \mathrm{~h}$ before Con A as a PBS solution containing 7.5\% ethanol (injection vol: $200 \mu \mathrm{l}$ ). $50 \mathrm{mg} / \mathrm{kg}$ cyclosporine A (Sandoz Ltd.,

1. Abbreviations used in this paper: ALT, alanine aminotransferase; AST, aspartate aminotransferase; Con A, concanavalin A; EM, electron microscopic; MHC, major histocompatibility complex; SCID, severe combined immunodeficiency syndrome; $\mathrm{SDH}$, sorbitol dehydrogenase; $T_{H}$ cell, $T$ helper cell; $T N F$, tumor necrosis factor. 
Basel, Switzerland) were injected intravenously 15 and $1 \mathrm{~h}$ before Con A in a vol of $300 \mu \mathrm{l}$. The solvent of cyclosporine A contained $7.3 \mathrm{mg} / \mathrm{ml}$ polyoxyethylene castor oil and $3.3 \mu \mathrm{l} / \mathrm{ml}$ ethanol in PBS. This was used as a control. FK 506 (Fujimycin, Fujisawa Pharmaceutical Co. Ltd., Osaka, Japan) was administered orally in a dose of $50 \mathrm{mg} / \mathrm{kg}$ (suspension: $5 \mathrm{mg}$ FK $506 / 1 \mathrm{ml} 1 \%$ tylose) $2 \mathrm{~h}$ before Con A challenge. Indomethacin was administered orally $1 \mathrm{~h}$ before Con $\mathrm{A}$ in a dose of 10 $\mathrm{mg} / \mathrm{kg}$, solution in $1 \%$ tylose.

The monoclonal anti-mouse Thy 1.2 antibody (in vivo cytotoxic antibody; Bio-Yeda, Rehovot, Israel) was intravenously administered $24 \mathrm{~h}$ before Con A in a volume of $100 \mu \mathrm{l}$ of the commercially available solution (according to the instructions of the supplier who does not specify the IgG concentration). Monoclonal anti-mouse CD4 and monoclonal anti-mouse CD8 were purchased from Boehringer, Mannheim, FRG. The animals received $100 \mu \mathrm{g}$ of anti-CD4 or antiCD8 intravenously $24 \mathrm{~h}$ before Con A challenge. Anti-mouse TNF $\alpha$ antiserum was given intravenously $15 \mathrm{~min}$ before Con $\mathrm{A}$ in a dose of 30,000 neutralizing units per mouse.

Silica particles with a diameter range of $0.5-5 \mu \mathrm{m}$ were kindly provided by Dr. Victoria Kolb-Bachofen, University of Düsseldorf, FRG. Each animal received a dose of $2.5 \mathrm{mg}$ in $200 \mu \mathrm{l}$ PBS intravenously and $2.5 \mathrm{mg}$ in $200 \mu \mathrm{l}$ PBS intraperitoneally $18 \mathrm{~h}$ before Con A.

Blood sampling for TNF, IL-1, or IL-2 measurement (see below) was carried out every hour after Con A administration starting at $0 \mathrm{~h}$ and ending at $8 \mathrm{~h}$.

Eight hours after Con A challenge, mice were sacrificed by cervical dislocation. Blood was withdrawn by heart puncture into $2.5 \%$ heparin. Lung, heart, liver, spleen, and kidneys were removed and fixed in $4 \%$ Formalin/PBS. The extent of liver injury was assessed by determination of serum alanine aminotransferase (ALT), serum aspartate amino transferase (AST), and serum sorbitol dehydrogenase (SDH) activities according to Bergmeyer (5). For histopathological evaluation 4- $\mu \mathrm{m} \mathrm{sec-}$ tions were stained with hematoxylin/eosin.

Cytokine assays. TNF in serum of mice was determined as described in reference 6 , serum IL-1 was assessed in a proliferation assay using the T cell clone D10G4.1 (7).

IL-2 in serum of mice was determined essentially as described in reference 8 with the modification of using the mouse cytotoxic T cell clone CTLL-2. Recombinant murine IL-2 (Boerhinger, Mannheim) was used as a standard. A monoclonal antibody directed against the murine IL-2 receptor (Boehringer, Mannheim) was used for checking specifity.

Proliferation assay. The spleen of BALB/c mice was removed and cells were pressed through a steel grid into RPMI 1640 medium, red blood cells were lysed by 5 -min incubation with $0.17 \mathrm{M} \mathrm{NH}_{4} \mathrm{Cl}$ at room temperature, spleen cells were washed twice with RPMI 1640 and $10^{6}$ cells/ml were incubated in RPMI 1640, 10\% FCS, $50 \mu \mathrm{M} \beta$-mercaptoethanol for $72 \mathrm{~h}$ at $37^{\circ} \mathrm{C}, 5 \% \mathrm{CO}_{2}$ with or without $1 \mu \mathrm{g} / \mathrm{ml}$ Con A. Proliferation was assayed using the reduction of the dye 3-[4,5-dimethylthiazol-2-yl]-2,5 diphenyltetrazolium (MTT tetrazolium, $5 \mathrm{mg} / \mathrm{ml}$ PBS, Sigma Chemical Co.) by viable cells as described elsewhere (9).

Cell preparation for FACS analysis. Monoclonal anti-mouse Thy1.2-fluorescein antibodies (Boehringer, Mannheim) were diluted to 50 $\mu \mathrm{g} / \mathrm{ml}$ with PBS containing $0.1 \%(\mathrm{wt} / \mathrm{vol}$ ) sodium azide and $0.1 \%(\mathrm{wt} /$ vol) BSA. $5 \times 10^{6}$ spleen cells were incubated for $1 \mathrm{~h}$ in $250 \mu \mathrm{l}$ of the antibody solution at $4^{\circ} \mathrm{C}$ in the dark, washed with $1 \mathrm{ml}$ PBS/BSA, resuspended, and fixed in a solution of PBS $/ 1 \%$ formaldehyde and kept in the dark at $4^{\circ} \mathrm{C}$. Cells were analyzed for fluorescence activity in a FACS Star Plus (B-D FACS Systems, Becton, Dickinson \& Co., Sunnyvale, CA). $1 \times 10^{4}$ cells were counted per analysis.

Electron microscopy. For electron microscopic (EM) investigations, livers of mice treated with $20 \mathrm{mg} / \mathrm{kg}$ Con A were removed after $4 \mathrm{~h}$ under nembutal anesthesia. Fixation was carried out by perfusion via the hepatic vein with $0.7 \%$ glutaraldehyde in $10 \mathrm{mM}$ sodium-cacodylate buffer containing $2 \mathrm{mM} \mathrm{CaCl}$ and $150 \mathrm{mM}$ saccharose $(10 \mathrm{~min}$, $\left.37^{\circ} \mathrm{C}, 370 \mathrm{mosM}\right)$. The tissue was cut into blocks of $1 \mathrm{~mm}^{3}$. After several washing steps specimens were postfixed with $2 \% \mathrm{OsO}_{4}$ in the same buffer $\left(2 \mathrm{~h}, 4^{\circ} \mathrm{C}\right)$. For transmission EM samples were dehydrated in an ascending series of ethanol and embedded in Spurr's resin. Ultrathin sections were contrasted with $1 \%$ uranylacetate and $1 \%$ alkaline lead citrate and viewed in a transmission electron micrograph (model 101, Siemens AG, Mannheim, FRG).

For scanning electron microscopy, after osmification following the steps mentioned above, samples were cryoprotected with $10 \%, 20 \%$, and $30 \%$ glycerol (each step for $30 \mathrm{~min}$, room temperature) and cryofixed in liquid propane. After transfer to liquid nitrogen they were broken up with a precooled razor blade. Dehydration was carried out in absolute methanol at $-80^{\circ} \mathrm{C}$ for $2 \mathrm{~d}$. After gentle warming up, specimens were critical-point-dried, mounted on aluminum stubs, sputtered with $15 \mathrm{~nm}$ gold-palladium and viewed in a scanning electron microscope (model 505, Philips Electronic Instruments, Mahwah, NJ).

Because of the massive lesions in liver tissue observed $8 \mathrm{~h}$ after Con A treatment (such as obstruction of microcirculation), fixation was also carried out by immersion with $2.5 \%$ glutaraldehyde in sodiumcacodylate buffer for $2 \mathrm{~h}$. The remaining steps were carried out as mentioned above.

Statistics. The results were analyzed according to Student's $t$ test. Data of transaminases and SDH are expressed as mean \pm SEM; $P$ $\leq 0.05$ was considered to be significant.

\section{Results}

Dose dependence of Con A-induced liver injury. When mice were intravenously injected with Con A, the animals suffered from acute liver failure. Histopathological inspection of the major organs showed no overt signs of organ injury except the liver. A dose $>1.5 \mathrm{mg} / \mathrm{kg}$ Con A led to a significant increase of serum transaminases and SDH activity within the next $8 \mathrm{~h}$ after the administration of the agent (Table I). No significant increase in $\gamma$-glutamyl transpeptidase activity or in alkaline phosphatase activity was found. This enzyme pattern and the AST/ALT ratio of $\sim 0.6$ suggests that a liver-specific lesion of the inflammatory rather than the necrotic type had been provoked by Con A. Boiled Con A preparations were ineffective.

Morphological findings. In stained thin sections of livers from Con A-treated mice, single small group necrosis became occasionally detectable by light microscopy. Portal areas as well as the parenchyma of the livers from Con A-treated mice were only scarcely infiltrated by leukocytes.

Table I. Dose Dependence of Con A-induced Liver Injury in Male NMRI Albino Mice

\begin{tabular}{cccccc}
\hline Treatment & AST & ALT & SDH & $n$ & $m$ \\
\hline$m g / k g$ & $U / l$ & $U / l$ & $U / l$ & & \\
None & $75 \pm 16$ & $40 \pm 4$ & $15 \pm 5$ & 6 & 0 \\
Con A & & & & & \\
0.15 & $110 \pm 16$ & $40 \pm 4$ & $20 \pm 4$ & 6 & 0 \\
1.5 & $190 \pm 37^{*}$ & $90 \pm 16^{*}$ & $50 \pm 8^{*}$ & 6 & 0 \\
7.5 & $265 \pm 39^{*}$ & $255 \pm 61^{*}$ & $195 \pm 61^{*}$ & 6 & 0 \\
15 & $910 \pm 414^{*}$ & $1,200 \pm 612^{*}$ & $620 \pm 336^{*}$ & 6 & 0 \\
20 & $2,130 \pm 673^{*}$ & $3,820 \pm 1,320^{*}$ & $1,100 \pm 377^{*}$ & 10 & 2 \\
30 & $6,400 \pm 1,880^{*}$ & $10,100 \pm 2,387^{*}$ & $4,240 \pm 1,049^{*}$ & 6 & 1 \\
& & & & & \\
\hline
\end{tabular}

Con A was intravenously injected. $n=$ number of animals per group, $m=$ number of animals which died within $8 \mathrm{~h}$. AST, ALT, and SDH were measured $8 \mathrm{~h}$ after Con A administration. Data are expressed as means \pm SEM. ${ }^{*} P \leq 0.05$ vs. untreated control. 

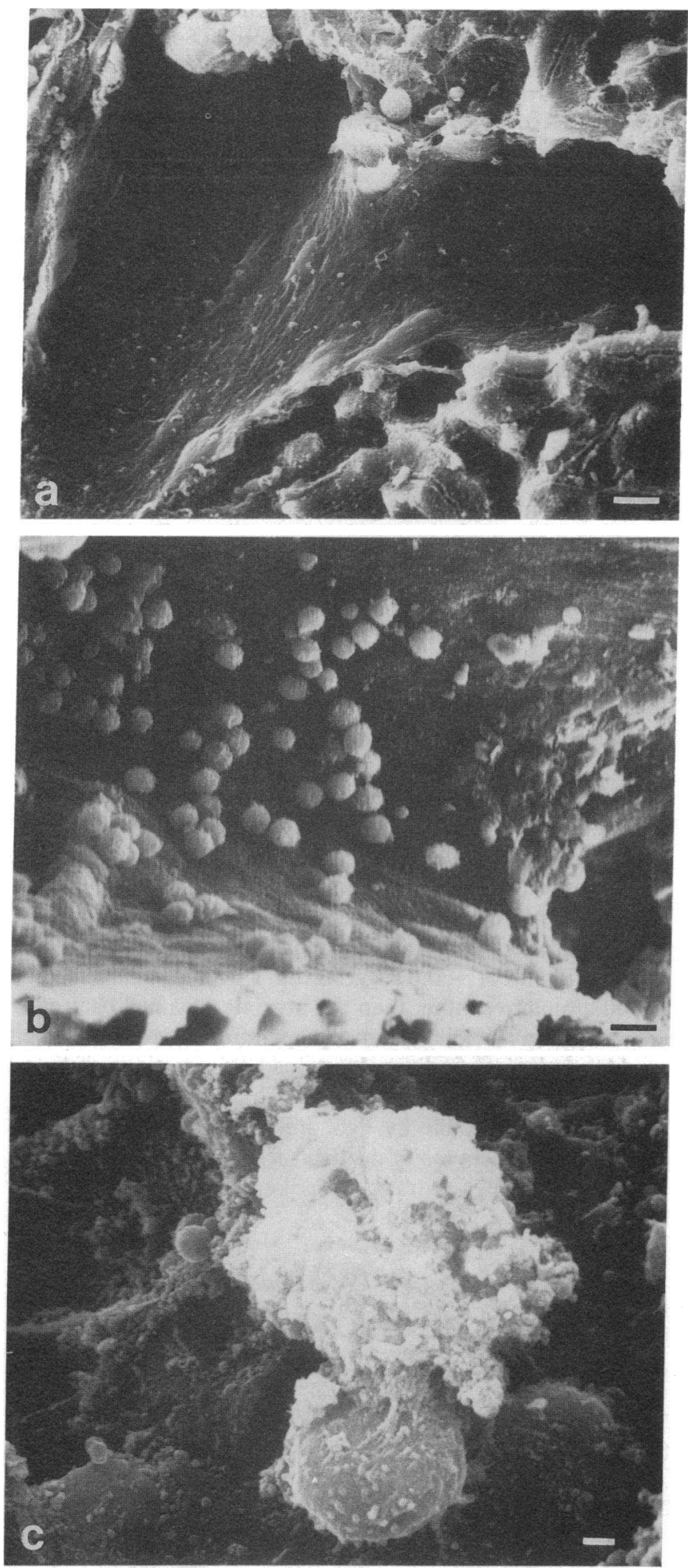

Figure 1. Scanning electron micrograph of lobular blood vessels of mouse livers fixed by perfusion. (a) Control. (b) $4 \mathrm{~h}$ after $20 \mathrm{mg} / \mathrm{kg}$ Con A given intravenously, showing attachment of blood cells to the endothelium. Bars $10 \mu \mathrm{m}$. (c) Detail $4 \mathrm{~h}$ after $20 \mathrm{mg} / \mathrm{kg}$ Con A given intravenously, showing the interaction between an activated macrophage (upper cell) and a lymphocyte (lower cell). Bar $1 \mu \mathrm{m}$.
To resolve the discrepancy between the extent of liver injury assessed by enzyme release as compared with apparently moderate histopathologically detectable lesions, a detailed EM examination was carried out. With this technique, severe morphological disintegration of the hepatic microarchitecture and cellular lesions were detected.

The freeze fracture technique used in combination with scanning EM investigations of liver tissue permitted an overview of morphological changes after Con A treatment. Compared with an untreated control liver (Fig. $1 a$ ), the micrograph in Fig. $1 b$ revealed, as the most striking phenomenon $4 \mathrm{~h}$ after Con A challenge, a pronounced sticking of leukocytes to the hepatic endothelium. At this time, disruption of endothelial cells or hepatocytes was hardly seen. A frequent observation was a direct interaction between activated macrophages and lymphocytes (Fig. $1 c$ ). Eight $\mathrm{h}$ after treatment, lymphocytes were found to stick to hepatocytes whose sinusoidal surface showed a rough appearance (Fig. $2 b$ ) compared with the flattened one seen in the control (Fig. $2 a$ ). In comparison to hepatocytes from control samples with their microvilli protruding into the space of Dissé (Fig. $2 a$ and Fig. $3 a$ ), the cell membrane of hepatocytes from Con A-treated animals had undergone
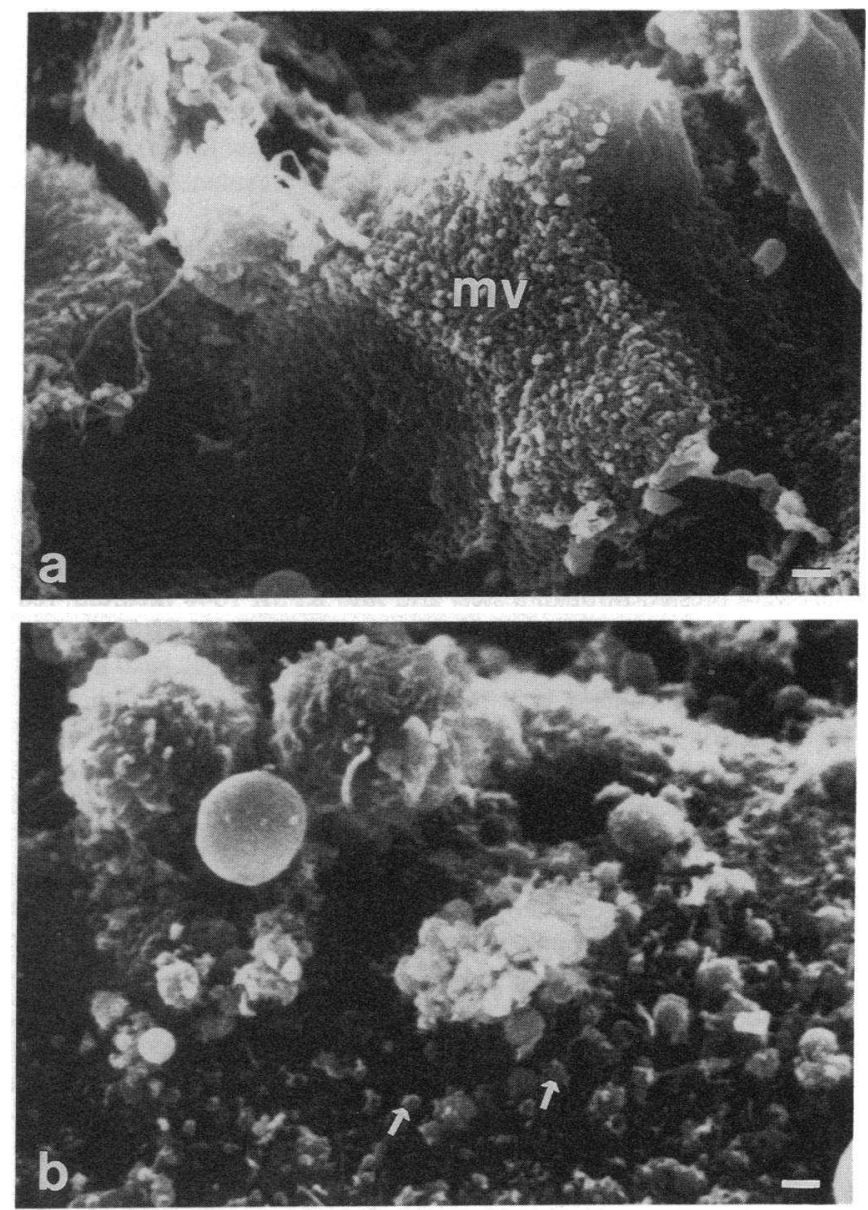

Figure 2. Scanning electron micrographs of mouse liver tissue fixed by immersion. (a) Control hepatocytes with normal microvilli $(m v)$. (b) $8 \mathrm{~h}$ after $20 \mathrm{mg} / \mathrm{kg}$ Con A given intravenously, with lymphocytes sticking to the hepatocytes. Arrows indicate cell surface irregularities with bleb formation. Bars $1 \mu \mathrm{m}$. 

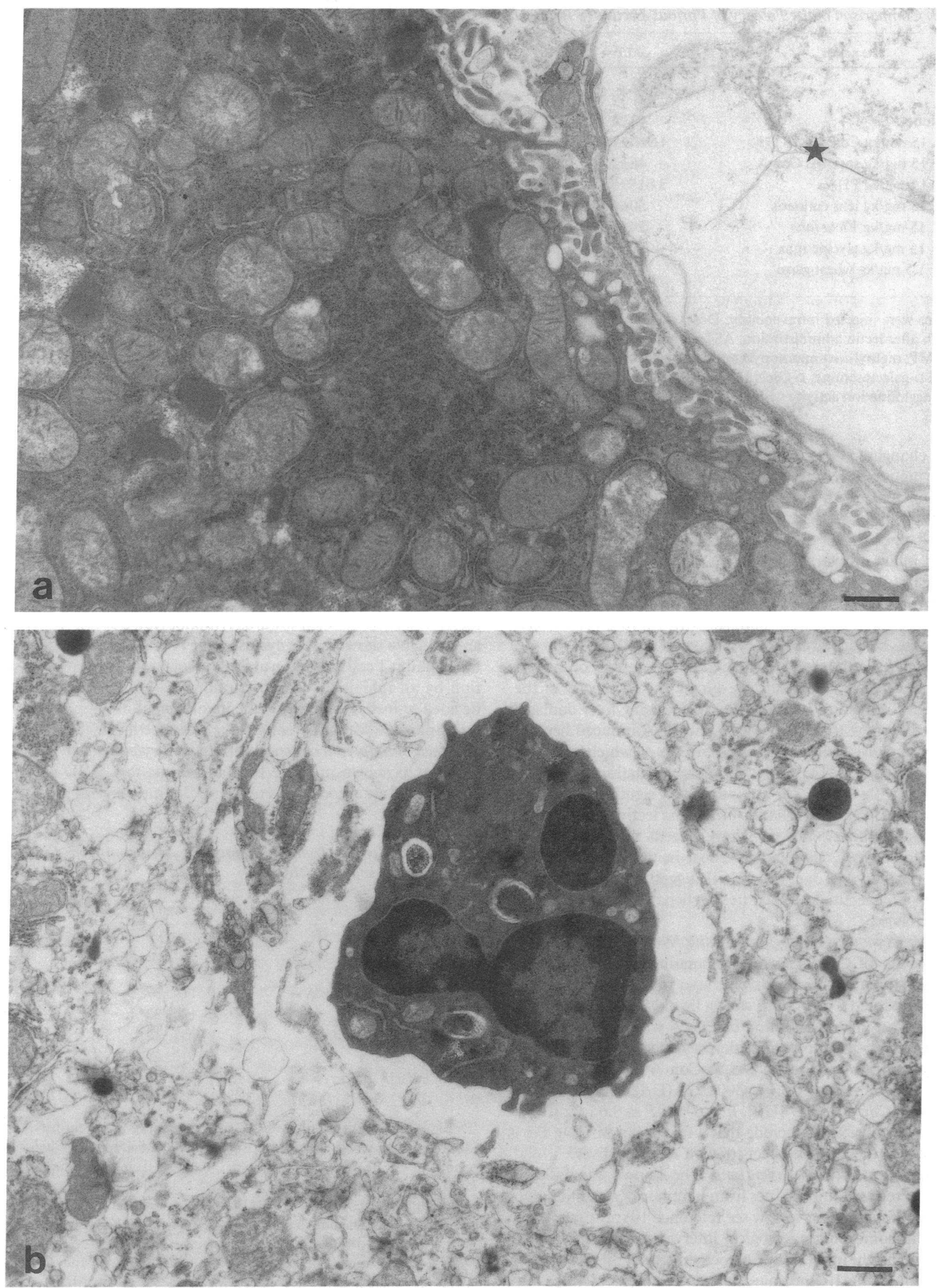

Figure 3. Transmission electron micrographs of immersion-fixed mouse liver tissue. (a) Control. The asterisk indicates the capillary lumen with denaturated blood plasma due to the fixation technique used. $(b) 8 \mathrm{~h}$ after $20 \mathrm{mg} / \mathrm{kg}$ Con A given intravenously, showing destroyed hepatocytes and endothelial cells with bleb formation on both cell types (the vascular lumen contains a neutrophil granulocyte). Bars $1 \mu \mathrm{m}$. 
Table II. Comparison of the Potency of Various Lectins to Induce Liver Damage in Male NMRI Albino Mice

\begin{tabular}{|c|c|c|c|c|}
\hline Treatment & ALT & $n$ & Sugar specificity & $\mathbf{R A A}^{\ddagger}$ \\
\hline & $U / l$ & & & \\
\hline None & $40 \pm 4$ & 6 & & \\
\hline $15 \mathrm{mg} / \mathrm{kg}$ Con $\mathrm{A}$ & $1,960 \pm 796^{*}$ & 6 & M- $\alpha$-D-MP, $\alpha$-D-Man, $\alpha$-D-Glc & 1 \\
\hline $15 \mathrm{mg} / \mathrm{kg}$ succinyl Con A & $46 \pm 20$ & 6 & M- $\alpha$-D-MP, $\alpha$-D-Man, $\alpha$-D-Glc & 0 \\
\hline $15 \mathrm{mg} / \mathrm{kg}$ PHA & $3,615 \pm 554^{*}$ & 3 & Oligosaccharide & 0.03 \\
\hline $15 \mathrm{mg} / \mathrm{kg}$ lens culinaris & $50 \pm 6$ & 6 & $\alpha$-D-Man & 4 \\
\hline $15 \mathrm{mg} / \mathrm{kg}$ Vicia faba & $24 \pm 5$ & 3 & M- $\alpha$-D-MP, D-Man, D-Glc & 4 \\
\hline $15 \mathrm{mg} / \mathrm{kg}$ glycine $\max$ & $30 \pm 10$ & 6 & D-GalNAc & 1 \\
\hline $1.5 \mathrm{mg} / \mathrm{kg}$ wheat germ & $40 \pm 20$ & 6 & (D-GlcNAc)2, NeuNAc & 2 \\
\hline
\end{tabular}

All lectins were injected intravenously. Doses of wheat germ lectin $>1.5 \mathrm{mg} / \mathrm{kg}$ were lethal. $n=$ number of animals per group. ALT was measured $8 \mathrm{~h}$ after lectin administration. AST and SDH values were analogous to the ALT data shown in the table. Mean \pm SEM. Abbreviations: M- $\alpha$-D-MP: methyl- $\alpha$-D-mannopyranoside; D-Man: D-mannose; $\alpha$-D-Man: $\alpha$-D-mannose; D-Glc: D-glucose; $\alpha$-D-Glc: $\alpha$-D-glucose; D-GalNAc: $N$-acetyl-D-galactosamine; D-GlcNAc: $N$-acetyl-D-glucosamine; NeuNAc: $N$-acetyl-neuraminic aicd. ${ }^{*} P \leq 0.05$ vs. untreated control. ${ }^{\ddagger}$ RAA: relative agglutination activity with erythrocytes (given by the supplier for each lot).

drastic changes. The surface was covered with cell debris and bleb formation was observed on hepatocytes (c.f., Fig. $2 b$ and Fig. $3 \mathrm{~b}$ ). Cell death of hepatocytes was unequivocally confirmed by transmission electron micrographs taken from mouse livers $8 \mathrm{~h}$ after challenge. Although control hepatocytes showed intact ultrastructural details such as microvilli, dense cytoplasma, and well-preserved mitochondria (Fig. 3 a), in livers from Con A-treated animals, the sinusoidal parts of the hepatocytes showed severe damage with ruptures of the cell membrane, blebs, and loss of cytoplasma (Fig. $3 \mathrm{~b}$ ).

Specificity of the lectin. Table II shows results of experiments that were carried out to evaluate the specificity of the lectin with respect to its capability of inducing liver damage. The results show that only Con A and PHA induced hepatotoxicity in equivalent doses. Succinyl Con A, which preserves its sugar specificity but is devoid of agglutination activity as compared with Con $\mathrm{A}$, did not induce any significant reaction of the liver. On the other hand, Vicia faba lectin, which shares the sugar specificity of Con A and exceeds the agglutination activity of Con A, also had no effect in the animals. These findings and further data in Table II suggest that agglutination activity of the lectins and their in vivo hepatotoxic potential do not correlate.

Specificty for the sugar-binding site. We wondered whether the capacity of Con A to bind to mannosyl residues was a prerequisite for its hepatotoxic in vivo properties. Therefore, we preincubated Con A with strong ligands for its sugar-binding site. The coadministration of Con A with $\alpha$-D-mannoside or methyl $\alpha$-D-mannopyranoside prevented the induction of hepatic injury by the lectin (ALT: Con A alone: 2,095 \pm 633 [U/l], $\alpha$-D-mannose + Con A: $300 \pm 234$ [U/l], $\alpha$-D-mannopyranoside + Con A: $30 \pm 9$ [U/1], $n=6-10, P \leq 0.05$ vs. Con A alone). We therefore conclude that a free sugar-binding site is required for the adverse effects of Con $\mathrm{A}$ on the liver.

Pharmacological interventions. The known capability of Con A to release lymphokines from lymphocytes and to induce their proliferation (for review see reference 10) prompted us to carry out some pharmacological intervention experiments to get more insight into the pathobiochemistry of this model. The results in Table III indicate that pretreatment of mice with either dexamethasone, FK 506, cyclosporine A protected against liver injury induced by Con $\mathrm{A}$. The morphological appearance of cyclosporine A-protected livers was not distinguishable from untreated control livers. On the other hand, high doses of indomethacin sufficient to inhibit eicosanoid synthesis (11) failed to show any significant effect. We conclude from this inhibition pattern that dexamethasone, rather than acting as an antiinflammatory agent, FK 506, as well as cyclosporine A, inhibited Con A-induced hepatitis by immunosuppressive actions directed towards lymphocytes. Several reports are available showing that cyclosporine A or FK 506 preferentially inhibit $T$ cell activation at the level of lymphokine production by an inhibition of transcription (12-16). We therefore decided to further investigate the involvement of lymphocytes by using mice with different genetic lymphocyte defects.

Lack of induction of hepatitis in lymphocyte-deficient mice. The results shown in Table IV demonstrate that SCID mice, which lack immunocompetent $\mathrm{T}$ and $\mathrm{B}$ lymphocytes (17), are

Table III. Effects of Immunosuppressive Agents on Con Ainduced Liver Injury in Mice

\begin{tabular}{lcr}
\hline \multicolumn{1}{c}{ Treatment } & ALT & $n$ \\
\hline & $U / l$ & \\
Con A & $4,970 \pm 1,529$ & 6 \\
Dexamethasone + Con A & $110 \pm 37^{*}$ & 12 \\
FK 506 + Con A & $130 \pm 32^{*}$ & 4 \\
Cyclosporine A + Con A & $58 \pm 12^{*}$ & 12 \\
Placebo + Con A & $3,510 \pm 2,464$ & 6 \\
Indomethacin + Con A & $3,480 \pm 1,576$ & 6
\end{tabular}

Dosages and application routes: Con A $20 \mathrm{mg} / \mathrm{kg}$ intravenously, dexamethasone: $500 \mu \mathrm{g} / \mathrm{kg}$ intraperitoneally $1 \mathrm{~h}$ before Con A administration; FK $506: 50 \mathrm{mg} / \mathrm{kg}$ p.o. $2 \mathrm{~h}$ before Con A challenge; cyclosporine A: $50 \mathrm{mg} / \mathrm{kg}$ intravenously $15 \mathrm{~h}$ and $1 \mathrm{~h}$ before Con A treatment; placebo (solvent of cyclosporine A solution, see Methods): intravenously $15 \mathrm{~h}$ and $1 \mathrm{~h}$ before Con A application; Indomethacin: $10 \mathrm{mg} / \mathrm{kg}$ orally $1 \mathrm{~h}$ before Con A. $n=$ number of animals per group. ALT was determined $8 \mathrm{~h}$ after Con A adminstration, AST and SDH data were analogous to ALT values. Mean \pm SEM. Serum ALT in untreated mice: $40 \pm 4 \mathrm{U} / 1 .{ }^{*} P \leq 0.05$ vs. result with Con $A$ alone. 
Table IV. Presence of Absence or Liver Injury in Immunocompetent or Immunodeficient Mice Treated with Con A

\begin{tabular}{lccr}
\hline Mouse strain & Challenge & ALT & $n$ \\
\hline & & $U / l$ & \\
BALB/c & None & $54 \pm 6$ & 3 \\
BALB/c & Con A & $2,020 \pm 566$ & 6 \\
SCID & Con A & $94 \pm 30^{*}$ & 4 \\
BALB/c nude & Con A & $80 \pm 9^{*}$ & 6
\end{tabular}

$20 \mathrm{mg} / \mathrm{kg}$ Con A was administered intravenously. $n=$ number of animals per group. ALT was determined $8 \mathrm{~h}$ after Con A treatment. AST and SDH data were analogous to ALT values. Means \pm SEM.

$* P \leq 0.05$ vs. result for BALB/c mice given Con A alone.

protected against the hepatotoxic effects of Con A. In an analogous experiment it was shown that athymic nude mice, which bear functionally defective, immature $\mathrm{T}$ lymphocyte populations (18) are also resistant against Con A-induced hepatitis. These findings provide strong evidence that $\mathrm{T}$ lymphocytes are involved in the pathogenesis of Con A-induced hepatitis.

Immunological interventions. The finding that $\mathrm{T}$-cells are involved in Con A-induced liver injury was further confirmed by immunological intervention studies: pretreatment of mice with a monoclonal antibody which in vivo destroys Thy 1.2 antigen-bearing $T$ cells abrogated the susceptibility of these animals towards the hepatotoxic properties of Con A (Table V). Proliferation capacity of spleen cells of anti-Thy 1.2 pretreated BALB/c mice towards Con A was tested in vitro and was found to be reduced by $83 \%$ compared with the control. FACS analysis of spleen cells of untreated BALB/c mice showed agreement with published data in that $37.3 \pm 5.1 \%(n$ $=3$ ) of the cells were stained by a monoclonal anti-mouse Thy 1.2 fluorescein antibody (19). In contrast, only $6.8 \pm 3.6 \%$ ( $n$ $=3$ ) of the spleen cells of anti-Thy 1.2 pretreated BALB/c mice were stained by anti-Thy 1.2 -fluorescein antibodies. This corresponds to a reduction of $82 \%$ of anti-Thy 1.2 fluorescein

Table V. Effects of MAbs Directed Towards T Lymphocytes or Subpopulations of $T$ Lymphocytes on Con A-induced Liver Injury in $B A L B / c$ Mice

\begin{tabular}{lccc}
\hline Pretreatment & Challenge & ALT & $n$ \\
\hline & & $U / l$ & \\
PBS & None & $50 \pm 3$ & 4 \\
PBS & Con A & $3,420 \pm 1,195$ & 4 \\
Anti-Thy 1.2 & Con A & $50 \pm 23^{*}$ & 4 \\
Anti-CD4 & Con A & $150 \pm 64^{*}$ & 5 \\
Anti-CD8 & Con A & $1,480 \pm 714$ & 5 \\
& & &
\end{tabular}

$100 \mu \mathrm{l}$ of the commercially available solution of monoclonal antimouse Thy 1.2 antibody was intravenously administered per animal $24 \mathrm{~h}$ before Con A. $100 \mu \mathrm{g}$ of monoclonal anti-mouse CD4 or monoclonal anti-mouse CD8 antibody, respectively, were intravenously injected per animal $24 \mathrm{~h}$ before the Con A challenge. $20 \mathrm{mg} / \mathrm{kg}$ Con A was given intravenously. $n=$ number of animals per group. ALT was determined $8 \mathrm{~h}$ after Con A treatment. AST and SDH values were analogous to ALT data. Mean \pm SEM. ${ }^{*} P \leq 0.05$ vs. result with PBS plus Con A. positive cells in anti-Thy 1.2 pretreated mice and matches well the data obtained with the proliferation test.

Furthermore, administration of a MAb directed against the CD4-glycoprotein of T cells completely protected against Con A-induced liver injury (Table V). In contrast, a MAb directed against the CD8-glycoprotein failed to protect against Con A hepatitis. We conclude from these findings that, in our model, the activation of $T$ helper $\left(T_{H}\right)$ cells by Con $A$ is obligatory to start the immunological response and finally to result in injury.

Moreover, the known in vivo destruction of macrophages by silica particles (20-22) resulted in prevention of Con A-induced liver injury (ALT: $150 \pm 36$ [U/l] compared with the Con A control with $6.960 \pm 1.710[\mathrm{U} / 1], n=6, P \leq 0.05$ ). This finding demonstrates the ancillary involvement of macrophages in the induction of Con $A$ hepatitis. These results suggest a mechanism of Con A-mediated organ injury involving a macrophage- $T_{H}$ cell interaction, which eventually leads to an activation of $T_{H}$ cells. Therefore, this activation step was further investigated by checking the release of IL-2 after Con A challenge.

$I L-2$ in sera of Con A-treated mice. The interaction between the $T$ cell antigen receptor of $C D 4+T_{H}$ cells and peptides presented by major histocompatibility complex (MHC) class II molecules on macrophages is known to induce the release of IL-1 from macrophages as well as the release of IL-2 from the CD4+ cells during the initiation of $T_{H}$ cell proliferation. Moreover, mitogen-activated $T_{H}$ lymphocytes secrete IL2 in the presence of IL-1-producing cells (23).

In sera of Con A-treated mice, only little IL-1-activity was found (near the detection limit). Serum IL-2 activity was measurable $2 \mathrm{~h}$ after intervention and reached a maximum $4 \mathrm{~h}$ after the Con A treatment (Fig. 4). This finding supports further evidence for the conclusion that $T_{H}$ cell activation is a key event in the pathogenesis of Con A-induced hepatitis.

Further discriminating experiments. It appears that the Con A model described so far is distinct from the exclusively macrophage-dependent, endotoxin-inducible hepatitis model in the galactosamine-sensitized mouse $(1,3)$. Several experiments were done to support this statement. Firstly, we checked

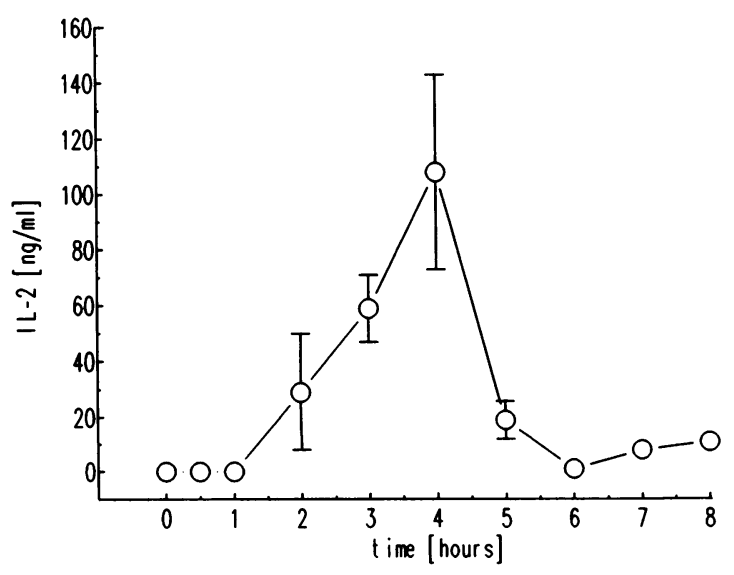

Figure 4. Time course of IL-2 release after Con A treatment. Con A was administered intravenously in a dose of $20 \mathrm{mg} / \mathrm{kg}$ at time point zero (h). Each time point represents a group of four NMRI mice, respectively. IL-2 in the sera of the animals was determined using a cellular assay based on the IL-2-dependent proliferation of the CTLL-2 cell line (cf. Methods). 
whether, as in the case of endotoxin (24), these mice could be rendered resistant by pretreatment with subtoxic doses of endotoxin. Mice that had received an intraperitonal injection of 5 $\mu \mathrm{g} / \mathrm{kg}$ of Salmonella abortus equi endotoxin $1 \mathrm{~h}$ before Con A were not tolerant against the lectin, however, they were protected against fulminant hepatitis induced by injection of 700 $\mathrm{mg} / \mathrm{kg}$ D-galactosamine plus $10 \mu \mathrm{g} / \mathrm{kg}$ endotoxin (data not shown). This experiment excludes the involvement of endotoxins in Con A-induced liver injury. Moreover, the known endotoxin-resistant mouse strain $\mathrm{C} 3 \mathrm{H} / \mathrm{HeJ}$ was not resistant against Con A-induced hepatitis, also suggesting that the mechanism of injury is not due to an endotoxin-mediated process. This experiment further shows that this mouse strain, in addition to NMRI and BALB/c mice, is also sensitive to Con A, i.e., that Con A sensitivity is not restricted to a certain mouse strain.

The predominant mediator of endotoxin-induced organ failure is TNF $\alpha$ (25). We therefore measured serum TNF in Con A-treated animals. Despite the fact that low serum TNF activity $(2.3 \mathrm{ng} / \mathrm{ml}$ total TNF within $8 \mathrm{~h})$ was found, pretreatment with antibody capable of neutralizing $2.5 \mu \mathrm{g}$ murine TNF $\alpha$ failed to protect against Con A-induced hepatitis. Therefore, it appears that TNF $\alpha$ is not primarily involved in this experimental disease.

\section{Discussion}

Lectins are proteins that bind to sugar residues on the surface of a wide variety of different cell types. Their biological properties include agglutination of bacterial, plant, or mammalian cells; mitogenic stimulation of $\mathrm{T}$ lymphocytes, which is associated with the release of biologically active polypeptides known as lymphokines; as well as the induction of cytotoxicity of lymphocytes and macrophages (for review see reference 10). The lectin-induced cytotoxic action of $T$ lymphocytes affects immunologically unrelated target cells and is attributed to the ability of the lectin to bridge effector and target cells (26) and to activate effector cells, i.e., T lymphocytes for killing the target cells (27).

In this study, liver parenchymal cells were clearly identified as the target cells of the in vivo toxicity of Con A. Indeed, it is known that hepatocyte plasma membranes strongly bind Con A (28). Moreover, Con A has been shown to bind to the insulin receptor present in liver tissue (29).

Ultrastructural evaluation clearly revealed adhesion of leukocytes to endothelial cells as an early event in liver damage. Obstruction of the microcirculation by blood cells became pronounced at later times and made it impossible to perfuse livers from Con A-treated animals $8 \mathrm{~h}$ after challenge. The prominent feature of the morphologically visible lesions was the complete disintegration of the endothelium, with subsequent cellular necrosis of hepatocytes. The chronological sequence: adhesion, endothelial cell detachment, bleb formation of parenchymal cells, does in fact explain why hepatocyte cell death could not be observed by light microscopy.

Our experiments with the SCID mouse strain and athymic nude mice as well as with antibodies directed against $T$ lymphocytes clearly identify the $\mathrm{T}$ lymphocyte as an effector cell in vivo. Subsidiary evidence for the involvement of $T$ cells comes from the pharmacological intervention experiments with cyclosporine A or FK 506. It has been described that the immunosuppresive activity of cyclosporine A as well as of FK 506 is not only due to inhibition of T cell-dependent IL-2 production, but also due to inhibition of the production of lymphotoxin $(\mathrm{TNF} \beta)$ and interferon $(14,15,30)$. Therefore, it seems feasible that Con A-stimulated lymphocytes release lymphokines such as TNF $\beta$, which in turn may act analogously to TNF $\alpha$ in inducing hepatic injury (2). Indeed, with a cellular assay detecting TNF $\alpha$ plus TNF $\beta$, small amounts of both cytokines were found in sera of Con A-treated mice. TNF activity in this assay was completely inhibited by an antiserum directed against TNF $\alpha$ (data not shown). However, administration of anti-TNF $\alpha$ antiserum failed to show any protective effect against Con $\mathrm{A}$, in contrast to a successful protection by the antiserum against endotoxin or TNF $\alpha$-induced hepatitis in galactosamine-sensitized mice (31). These findings indicate that TNF is unlikely to be involved in Con A-induced hepatitis. On the other hand, the observed IL-2 production is most probably a result of $\mathrm{T}$ lymphocyte activation. Therefore, concerning TNF or IL-2, we favor the view that cytokine release is a bystander effect rather than a causal cytotoxic event in our model.

Our findings also indicate that it is neither the agglutination capacity nor the sugar specificity per se that determines the in vivo hepatotoxic potential of the lectin Con A. It appears that Con A substitutes for the signal provided by macrophages through peptides bound to MHC class II molecules. Indeed, it has been shown by others (32) that Con A binds to the MHC of target cells. The involvement of macrophages in Con A hepatitis was not only shown by the absence of Con A-inducible lesions in macrophage-depleted animals but also by the morphological demonstration of macrophage-lymphocyte interactions. Thus, this experimental disease is probably produced by both lymphocytes and macrophages. The protection by antiCD4 antibodies against Con A suggests a mechanism in which CD4+-bearing $\mathrm{T}_{\mathrm{H}}$ cells recognize the Con A-modified MHC structures of macrophages and become activated. Such a mechanism, i.e., $T_{H}$ cell activation followed by inflammatory tissue destruction, is held responsible for the autoimmune disease rheumatoid arthritis (33).

The finding that the liver is the target organ of Con A-induced toxicity in vivo may be due to the fact that this organ contains the majority of macrophages in the body, namely the Kupffer cells. After intravenous injection of Con A, this resident macrophage population exposed to the circulation is primarily reached by the lectin. Therefore, it also seems likely that $T$ cell activation first starts within the liver and thus explains the distinct organotropy of Con A in terms of toxicokinetics.

Two chronic $\mathrm{T}$ cell-dependent liver injury models have been described so far, i.e., a bacterial cell wall-induced hepatic granuloma in genetically susceptible rats (34) as well as a murine inflammatory liver model induced by injection of liver homogenate in an adjuvant (35). In the present investigation, not only the involvement of $\mathrm{T}$ cells was shown, but also their activation (as demonstrated by systemic IL-2 release). The practical gain of our T cell-mediated murine autoreactive hepatitis consists in the possibility to study cause and effect relationships in an animal model and to further explore possible intervention strategies by testing immunosuppressive drugs.

The experimental liver injury described here is of considerable interest as relates to the pathophysiology of autoimmune diseases in man. An example is chronic active hepatitis (36), a condition that leads to progressive destruction of liver paren- 
chymal cells by activated $\mathrm{T}$ cells. The pharmacological intervention profile obtained here against Con A-induced hepatitis exhibits close analogies to the efficacy of cyclosporine A against experimental allergic encephalomyelitis in rats (37) as well as to successful treatment of autoimmune diseases in man with FK 506 (38). We consider the Con A-induced hepatitis as a disease model where self or foreign antigen presentation by macrophages and recognition by $T_{H}$ lymphocytes is mimicked by the lectin Con $\mathrm{A}$ at the final step of a common activation pathway. This sequence of cellular activation of the reticuloendothelial system may be relevant for many autoimmune diseases, including systemic lupus erythematodes, rheumatoid arthritis, type I diabetes, and multiple sclerosis.

\section{Acknowledgments}

We thank Dr. Mossmann for kindly providing SCID mice. We are indebted to Dr. P. Scheurich, Department of Cellbiology and Immunology, University of Stuttgart, FRG, for carrying out the FACS analyses, as well as to Dr. H. Plattner, Department of Ultrastructure Research, University of Konstanz, FRG, for theoretical and practical support during the morphological studies. The help of Dr. D. Rohm and Dr. U. Schwulera, Biotest Pharma, Dreieich, FRG, who provided the CTLL-2 cell line, is gratefully acknowledged. We thank Dr. R. Lesch, City Hospital, Department of Pathology, Konstanz, FRG, for orientating histopathological evaluation. Interactive discussions with Dr. H. Kolb and Dr. V. Kolb-Bachofen, Düsseldorf, Germany, are gratefully acknowledged.

\section{References}

1. Tiegs, G., and A. Wendel. 1988. Leukotriene mediated liver injury. Biochem. Pharmacol. 37:2569-2573.

2. Tiegs, G., M. Wolter, and A. Wendel. 1989. Tumor necrosis factor is a terminal mediator in galactosamine/LPS-induced hepatitis in mice. Biochem. Pharmacol. 38:627-631.

3. Freudenberg, M. A., D. Keppler, and C. Galanos. 1986. Requirement for lipopolysaccharide-responsive macrophages in galactosamine-induced sensitization to endotoxin. Infect. Immun. 51:891-895.

4. Kelso, A., and N. Gough. 1987. Expression of hemopoietic growth factor genes in murine T lymphocytes. In Lymphokines. Vol. 13. D. R. Webb, and D. V. Goeddel, editors. Academic Press Inc., London. 209-238.

5. Bergmeyer, H.-U. 1984. Methods of Enzymatic Analysis. 3rd edition. Verlag Chemie, Weinheim, FRG.

6. Espevik, T., and J. Nissen-Meyer. 1986. A highly sensitive cell line, WEHI 164 clone 13, for measuring cytotoxic factor/tumor necrosis factor from human monocytes. J. Immunol. Methods. 95:99-105.

7. Beuscher, H. U., C. Günther, and M. Röllinghoff. 1990 . IL-1 $\beta$ is secreted by activated murine macrophages as biologically inactive precursor. J. Immunol. 144:2179-2183.

8. Tada, H., O. Shiho, K.-I. Kuroshima, M. Koyama, and K. Tsukamoto. 1986. An improved colorimetric assay for interleukin 2. J. Immunol. Methods. 93:157-165.

9. Mosmann, T. 1983. Rapid colorimetric assay for cellular growth and survival: application to proliferation and cytotoxicity assays. J. Immunol. Methods. 65:55-62.

10. Lis, H., and N. Sharon. 1986. Biological properties of lectins. In The Lectins: Properties, Functions and Applications in Biology and Medicine. J. E. Liener, N. Sharon, and I. J. Goldstein, editors. Academic Press, Inc., London. 256-291.

11. Shakir, K. M., J. T. O'Brian, and S. L. Gartner. 1985. Enhanced phopholipase $\mathrm{A} 2$ activity in rat plasma, liver, and intestinal mucosa following endotoxin treatment: a possible explanation for the protective effect of indomethacin in endotoxin shock. Metabolism. 34:176-182.

12. Elliot, J. F., Y. Lin, S. B. Mizel, R. C. Bleackley, D. G. Harnish, and V. Paetkau. 1984. Induction of interleukin 2 messenger RNA inhibited by cyclosporine A. Science (Wash. DC). 226:1439-1441.

13. Krönke, M., W. J. Leonard, J. M. Depper, S. K. Arya, F. Wong-Staal, R. C. Gallo, T. A. Waldmann, and W. C. Greene. 1984. Cyclosporine A inhibits
T-cell growth factor gene expression at the level of mRNA transcription. Proc. Natl. Acad. Sci. USA. 81:5214-5218.

14. Granelli-Piperno, A., L. Andrus, and R. M. Steinman. 1986. Lymphokine and nonlymphokine mRNA levels in stimulated human T cells. Kinetics, mitogen requirements, and effects of cyclosporine A. J. Exp. Med. 163:922-937.

15. Tocci, M. J., D. M. Matkovich, K. A. Collier, D. Kwok, F. Dumont, S. Lin, S. Degubicibus, J. J. Siekierka, J. Chin, and N. J. Hutchinson. 1989. The immunosuppressant FK 506 selectively inhibits expression of early T-cell activation genes. J. Immunol. 143:718-726.

16. DeFranco, A. L. 1991. Immunosuppressants at work. Nature (Lond.). 352:754-755.

17. Dorshkind, K., G. M. Keller, R. A. Phillips, R. G. Miller, G. C. Bosma, M O'Toole, and M. J. Bosma. 1984. Functional status of cells from lymphoid and myeloid tissues in mice with severe combined immunodeficiency disease. J. Im munol. 132:1804-1808.

18. Kung, J. T. 1988. Impaired clonal expansion in athymic nude CD8+ CD4- T cells. J. Immunol. 140:3727-3735.

19. Ledbetter, J. A., and L. A. Herzenberg. 1979. Xenogenic monoclonal antibodies to mouse lymphoid differentiation antigens. Immunol. Rev. 47:63-90.

20. Allison, A. C., J. S. Harington, and M. Birbeck. 1966. An examination of the cytotoxic effects of silica on macrophages. J. Exp. Med. 124:141-161.

21. Levy, M. H., and E. F. Wheelock. 1975. Effects of intravenous silica on immune and non-immune functions of the murine host. J. Immunol. 115:41-48.

22. Brosnan, C. F., M. B. Bornstein, and B. R. Bloom. 1981. The effects of macrophage depletion on the clinical and pathologic expression of experimental allergic encephalomyelitis. J. Immunol. 126:614-620.

23. Robb, R. J. 1982. Human T-cell growth factor: purification, biochemical characterisation and interaction with a cellular receptor. Immunobiology. 161:21-50.

24. Freudenberg, M. A., and C. Galanos. 1988. Induction of tolerance to lipopolysaccharide-D-galactosamine lethality by pretreatment with LPS is mediated by macrophages. Infect. Immun. 56:1352-1357.

25. Beutler, B., J. W. Milsark, and A. C. Cerami. 1985. Passive immunization against cachectin/tumor necrosis factor protects mice from lethal effect of endotoxin. Science (Wash. DC). 229:869-871.

26. Asherson, G. L., J. Ferluga, and G. Janossy. 1973. Non-specific cytotoxicity by $T$ cells activated with plant mitogens in vitro and the requirement for plant agents during the killing reaction. Clin. Exp. Immunol. 15:573-589.

27. Parker, W. L., and E. Martz. 1980. Lectin-induced nonlethal adhesion between cytolytic $T$ lymphocytes and antigenically unrecognizable tumor cells and nonspecific "triggering" of cytolysis. J. Immunol. 124:25-35.

28. Ferayorni, L. S., P. N. McMillan, L. Raines, C. O. Gerhardt, and H. O. Jauregui. 1983. Lectin binding to adult rat liver in situ, isolated hepatocytes, and hepatocytes cultures. In Isolation, Characterization, and Use of Hepatocytes. R. A. Harris, and N. W. Cornell, editors. Elsevier Science Publishing Co. Inc., New York. 271-276.

29. Roth, R. A., D. J. Cassell, B. A. Maddux, and J. D. Goldfine. 1983. Regulation of insulin receptor kinase activity by insulin mimickers and an insulin antagonist. Biochem. Biophys. Res. Commun. 115:245-252.

30. McKenna, R. M., K. Szturm, J. R. Jeffery, and D. N. Rush. 1989. Inhibition of cytokine production by cyclosporine A and G. Transplantation (Baltimore). 47:343-348.

31. Tiegs, G., M. Niehörster, and A. Wendel. 1990. Leukocyte alterations do not account for hepatitis induced by endotoxin or TNF $\alpha$ in galactosamine-sensitized mice. Biochem. Pharmacol. 40:1317-1322.

32. Keren, Z., and G. Berke. 1984. Selective binding of concanavalin A to target cell major histocompatibility antigens is required to induce non-specific conjugation and lysis by cytolytic T lymphocytes in lectin-dependent cytotoxicity. Cell. Immunol. 89:458-477.

33. Harris, E. D. Jr. 1988. Pathogenesis of rheumatoid arthritis: a disorder associated with dysfunctional immunoregulation. In Inflammation: Basic Principles and Clinical Correlates. J. I. Gallin, I. M. Goldstein, and R. Snyderman, editors. Raven Press, New York. 751-773.

34. Wahl, S. M. 1988. Fibrosis: bacterial-cell-wall-induced hepatic granulomas. In Inflammation: Basic Principles and Clinical Correlates. J. I. Gallin, I. M. Goldstein, and R. Snyderman, editors. Raven Press, New York. 841-860.

35. Lohse, A. W., M. Manns, H.-P. Dienes, K.-H. Meyer zum Büschenfelde, and I. R. Cohen. 1990. Experimental autoimmune hepatitis: disease induction, time course, and T cell reactivity. Hepatology. 11:24-29.

36. Wermers, G. W., H. Band, and E. J. Yunis. 1988. Role of the HLA system in antigen recognition and disease. In The Liver: Biology and Pathobiology. I. M. Arias, W. B. Jakoby, H. Popper, D. Schachter, and D. A. Shafritz, editors. 2nd ed. Raven Press, New York. 885-896.

37. Borel, J. F., C. Feurer, H. U. Gubler, and H. Stähelin. 1976. Biological effects of cyclosporin A: a new antilymphocytic agent. Agents Actions. 6:468-475. 36.
38. Thomson, A. W. 1990. FK 506 enters the clinic. Immunol. Today. 11:35- 